\title{
THE BEGINNING OF THE EUROPEAN RENAISSANCE
}

\author{
Mahmudov Otabek \\ Doctor of philosophy (PhD), Head of Department of World History of Fergana State University, \\ Republic of Uzbekistan
}

Article DOI: https://doi.org/10.36713/epra4787

\begin{abstract}
In article on the basis of careful analysis of the scientific literature devoted to history of the translations in Spain in XII-XIII centuries, the place of the Toledo school in the formation of the Renaissance process in Europe is revealed. In addition, the historical significance of this school in the translation and study of the works of scholars of the medieval Muslim East is assessed. As a result of the analysis of political, social and cultural processes that took place in the VIII-XII centuries on the Iberian Peninsula, the historical factors that influenced the formation of the Toledo school are established, and it is also proved that the period of mutual synthesis of East and West cultures was the main historical factor in the formation of the school. The scientific and methodological foundations of views on the stages of the Toledo school's activity, the staff, tasks, as well as translators and scientists who worked at the school are revealed. based on this, it is proved that the Toledo school is the logical beginning of the Renaissance of the West.
\end{abstract}

KEYWORDS: Toledo school, Renaissance, Spain, Europe, Muslim East, Middle Ages, Arab, Castilian, Latin, translations, translators.

\section{INTRODUCTION}

In a number of countries around the world, special attention is paid to translation activities carried out in cities of Spain, such as Toledo, Saragossa, Segovia, Navarre, Seville and Barcelona in the XII-XIII centuries. Among these centers, the role of the Toledo school in the history of science is considered very important, as a result, research is conducted in priority areas of this subject. Despite this, questions about the creation of the school, its composition, translation works, scientific activities in the school, the life and work of translators and scientists have not yet been fully studied in its entirety.

1.1. Literatures review. The scientific research of foreign scientists M-T. de Alverny [1], J.Gil [8], S.Hayyek [10], C.Burnett [2], R.Henelde Abecasis [11], K.Foz [5], M.Gargagliati [6], M.Robinson [19] and A.Fidora [4] are the most important works on the study of problems related to the Toledo school. They scientifically analyze the issues of formation and activity of the school.

To date, the history of science that developed in Europe in the XII-XIII centuries. Studied by scientists in the region. In this regard, the translation activity of that time was not left out of the attention of researchers. The works of F.Carmody [3], C.Haskins [9], L.Thorndike [20] and E.Grant [7] are considered major studies in this field.

Despite this, the lack of fundamental work in this direction requires a deep scientific research, covering in a comprehensive way the problems related to the creation of the Toledo school, the composition, tasks, life and work of translators, translation and scientific activities, as well as research works of scholars of the Muslim East in the school.

I have also been conducting scientific research in this area for several years $[12,13,14,15$, $16,17,18]$. As a result of this research, in 2018 defended my doctoral dissertation on the topic "The 


\section{EPRA International Journal of Research and Development (IJRD)}

place of the Toledo School in the study of the scientific heritage of Central Asian scientists in Europe (XII - XIII centuries)". Today, continuing its scientific research expanded the geography of its research. Now, my dissertation for the degree of doctor of science (DSc) is called "Studying the scientific heritage of Eastern scientists in the translation centers of medieval Europe". This article is another result of my research on the topic.

1.2. Objective. The objective of the study is to reveal the place of the Toledo school in the formation of the Renaissance process in Europe. In addition, assess the historical significance of this school in the translation and study of the works of scholars of the medieval Muslim East.

\section{MATERIAL AND METHODS}

\section{1. "The historical roots of the Toledo} school: factors that contributed to its formation". This section analyzes the political, social and cultural processes that occurred in the city of Toledo from ancient times to the XII century, that is, during the Roman Empire $(193 \mathrm{BC}-411)$, the Alans (411-469), the Kingdom of the Visigoths (469-712), the Arab Caliphate (712-756), the Emirate of Cordoba and the Caliphate (756-9291031), as well as the Emirate of Toledo (1031-1085), and describes individual factors that became the basis of the to form a school. The result of the analysis is that Toledo, located in the very center of the Iberian Peninsula, has been the basis of numerous civilizations since ancient times. The main factor is that due to its convenient geographical location, the city has always been considered the most important strategic center.

As one of the historical factors that directly influenced the formation of the Toledo school, we can point to the development of scientific processes that occurred during the reign of the Emir of Toledo, Yahya al-Ma'mun (1043-1075). Al-Ma'mun, paying special attention to attracting major scientists to his Palace, tried to create the necessary conditions for them. In particular, scientists who came from different parts of the Iberian Peninsula worked in his Palace, such as doctors: al-Wafid, Ibn Walif, alLukuh; astronomers az-Zarkali, Ibn Assafor, asSahli; mathematics - al-Waccadi, at-Tujibi, Ibn alAttar, Ibn Khamis, Ibn al-Binus, geographer and engineer Ibn Bassal and historian Sayid at-Tolitoli. The paper pays special attention to the life and work of the above-mentioned scientists. An important aspect is that the scientific legacy left by them later contributed to the formation of the Toledo school and as a "local source" assisted the research of scientists who worked there [12. p. 24].

The work that served as the most important factor for the formation of the Toledo school was carried out by the king of Leon and Castile, Alphonse VI (1069-1109), who in 1085, having restored Christian power in Toledo, made it the capital of his state. It is known that a large library was established in Cordoba by Caliph Abdurahman III (912-962). The real library during the reign of his son al-Hakam II (961-976) became even richer, and the number of books reached more than 400 thousand. During the offensive of Alphonse VI in Cordova, he took possession of the remaining part of the books, took them to Toledo as a trophy. The king, in order to preserve these manuscripts, gave instructions to place them in the Cathedral Church. The above works were translated into Latin by translators of the Toledo school from the beginning of the twelfth century. At the same time, it should be noted that at one time, by order of Abdurakhman III, the first European paper production workshops were established in Toledo. As a result, the city becomes a major paper producer in the region. The rich experience of the Toledo masters accumulated in this industry subsequently ensured that paper needs were met in a timely manner during the period of extensive development of manuscript copying and translation work.

Another aspect that became the basis for the formation of the school in Toledo was the mutual mixing of the cultures of the East and West in the VIII-XII centuries, that is, the period of synthesis that occurred. This process has become not only a period of mutual enrichment of cultures of different peoples, but also a period of formation of a society with a new mindset. The transformation of Toledo into a scientific center where representatives of three religions worked together side by side: Muslims, Christians, and Jews, prompted scientists from all countries and cities in the region to create in this place. As a result, in the XII-XIII centuries, the ground was prepared for the formation of the Toledo school - a "transit point" that transmitted the achievements of science from the East to the West.

2.2. "Stages of activity, composition and tasks of the Toledo school". Exact information about the year of establishment of the Toledo school is still unknown. And the term "Toledo school" was first used by historians of the last century in order to generalize the activities of a team of translators who were engaged in creative work in the city of Toledo in the XII-XIII centuries.

Based on the results of analysis of the data obtained in the course of the study, we came to the conclusion that the formation and activities of the school should be divided into 3 stages.

Stage I - covers the years 1125-1152, that is, the period when a man named Raimondo de Salveta worked as Archbishop of the city of Toledo. It was on his initiative that a special group of translators was formed to translate works in Arabic that were 


\title{
EPRA International Journal of Research and Development (IJRD)
}

\author{
Volume: 5 | Issue: 7 | July 2020 \\ - Peer Reviewed Journal
}

located in the Cathedral Church. This leads to the conclusion that Raimondo played a major role in the formation of the school. During the above period, works related to astrology, astronomy, and mathematics were mostly translated. During this period, by order of Raimondo, in order to create favorable conditions for members of the school, the Cathedral Church of Toledo was restored again and additional special rooms were built for translating and writing works [17. p. 5-8].

In the second stage - the joint activity of translators in pairs deserves attention. During this period, translations of philosophical and medical works were created. Also, translations of individual works related to natural and exact Sciences are processed. At this stage, which covers the period from 1152 to the second half of the XIII century, translation work turns into a well-organized permanent activity. Based on the created conditions for translation activities and the centralized mode of work, this period can be called as a fully formed period of the Toledo school. During this period, the organizational services of the archbishops of Toledo, John Castellmorona (1152-1166) and Rodrigo Jimenez de Rada (1202-1247) were great [18. p. 1420].

Stage III - coincides with the period of the reign of King Alphonse X of Castile, i.e. 1252-1284 years. According to reports, Alphonse X, along with overseeing the school's activities, personally edited the newly created individual translations. During this period, certain works translated into Latin in previous periods began to be translated into Spanish of the Castilian dialect, in connection with the Declaration of it as the state language. Along with exact and natural Sciences, translation of works related to literature, editing of translations by a special proofreader is considered a special peculiarity of this period. Despite this, during this period, the circle of activity of the Toledo school is narrowing, in a certain sense, its former glory is decreasing. The reason for this was that the king paid great attention and time to the newly created scientific and cultural center - in Seville [16. p. 3-7].

The school's location took over the library and the special offices of the Cathedral Church adjacent to it. Special-service rooms were built on the initiative of Raymond, John and Rodrigo in different years, based on the need. The above premises consisted of parts intended for translators, copyists, bookbinders, they were equipped based on their needs. Apparently, there were additional rooms that are adapted for other processes related to the conduct of scientific discussions and writing of books. They are an integral part of the school.

The school operated under the personal guidance and patronage of archbishops Raimondo,
John, Rodrigo, and King Alphonse X. This is confirmed by their personal management of the work related to the selection of a work for translation, the appointment of a translator responsible for the translation, as well as financial support. It is this aspect that means that the above-mentioned persons were at one time the highest leaders of the Toledo school. In the school, after the top Manager, there was a position responsible for the day-to-day activities of the institution. The famous translator Domingo Gundisalvo is the first person appointed to this position of "head of records management" [13. p. 3-7].

Another position of the school was called "eméndador" ("spotter") it was introduced at the initiative of Alphonse X in the second half of the XIII century. The person holding this position performed editorial editing of the created translations. The next responsible person in the school was the "magister" ("master"), the persons with this status at the same time consisted of three or four people and they led the activities in a certain direction. At the Toledo school, in addition to the heads of responsible managers, scientists and translators, a group of employees performed practical work such as copying, providing services to readers, master bookbinders and delivering translated works to their customers.

One of the original tasks of the Toledo school was to collect various works in Arabic, store and provide services to readers. As a result of the need to find out the content of books, his main task was formed - translation. Many members of the school were not only simple translators, but also major scientists in their field [15. p. 534-536]. They, in addition to translation work, undertake the research directly studying the works of the Arabic language. This means that over time, the school's tasks have expanded to include responsibility for research. In some studies, it is noted that the school held classes in Arabic and astrology, this information might contribute to the basis to claim that the tasks of the Toledo school included teaching.

2.3. "Translators of the Toledo school and their activities". The main group of translators who carried out their activities at the school consisted of people from different countries of Europe. Of these, the Spaniards - John of Seville, Domingo Gundisalvo, John of Spain, Mark of Toledo, Alvaro de Oviedo; the English - Adelard of Bath, Alfred of Sareshel and Michael Scot; the Italians - Gerard of Cremona, Herman of Germany; the Jews - Ibn Daud, Ya'ud Ibn Moshe Cohen, Ishaq Ibn Sid, Abraham de Toledo, Samuel de Toledo; the Flemish - Rudolf of Bruges. In addition to them, commissioners and members of the school supported the collaborative relationships with translators living in other cities. 


\title{
EPRA International Journal of Research and Development (IJRD)
}

\author{
Volume: 5 | Issue: 7 | July 2020 \\ - Peer Reviewed Journal
}

Also, financial support and encouragement of the creativity of these translators in many cases was provided by the school's management. Avraham barHia, who lived in Barcelona, and Plato of Tivoli; Pedro Alfonso, who lived in Saragossa, Herman of Dalmatia, and Hugo of Santali; Robert of Chester, who lived in Segovia; and Robert of Ketton, who lived in Navarre, were among the school's collaborators.

Many of them were not only simple translators, but also outstanding experts in their profession. The above-mentioned scientists together with the implementation of translation activities, having studied directly the works in Arabic, wrote their books on the basis of them. Proof of this can be given in the example of written works, called lat. "Regulae abaci" ("Work in the abacus") by Adelard of Bath, related to the science of calculus, "Liber de Judiciis Astrologiae" ("Book of astrology reflection") by John of Seville, referring to astronomy, "alAqidah ar-raffiyah" ("the Great faith") by Ibn Daud, referring to philosophy, "Liber introductorius" ("Book of introduction") by M. Scot, which has an encyclopedic character.

Brief conclusion in this direction is the fact that as a result of their work numerous valuable books, belonging to Peru stars of science the ancient period and the great thinkers of the East, were translated into Latin and Castilian Spanish, as well as scientific theories in them have become a spiritual treasure of all the peoples of the European region.

2.4. "Translations made at the Toledo school and their significance". The process of translation school of Toledo was carried out in a more complex system, over time this system changed, evolved. Initially, works in Arabic were translated first into the local Castilian or Hebrew languages, only later translated into Latin. More precisely, a person who knows Arabic, the translation of the work was transmitted orally in the local Castilian or Hebrew language to his partner, who knows Latin, the second person, in turn, translated everything he heard in writing into Latin. The reason for this process was the ignorance of some translators of the Arabic language, and others of the Latin language. Based on this, if you look at the activities of the school from this point of view, you can see that in many cases their members carried out their activities together. In some cases, this method has caused the creation of works with various errors, which were translated from works with different levels of complexity. Therefore, some translations of the works were later corrected.

If you pay attention, among the representatives of the school were translators who have the ability to translate directly into Latin. For example, Adelard of Bath, John of Seville, Gerard of
Cremona, Michel Scott, Mark of Toledo and Herman of German are among them. Of these, the translations of Gerard, Michael, Mark, and Herman are distinguished by their scientific excellence. In addition, John of Seville, in certain works that he translated into Latin, deliberately did not translate geographical information and information related to the Islamic religion. He translated only the main idea of individual works. Of course, this "method" has had a significant negative impact on the scientific level of the work. This "method" is also inherent in the work of Adelard of Bath.

\section{RESULTS}

If you look at the list of works that were translated into Latin at the school of Toledo in the XII-XIII centuries, you can see that in the first time a lot of attention was paid to the translation of works related to such fields of science as astrology, astronomy, mathematics and medicine. Subsequently, in particular from the second half of the XII century, translations into Latin of works related to philosophy became widespread. Since the second half of the 13th century, examples of fiction have been included in the list of these works.

The total number of works that have been translated is 98 works, they belong to the pen of 43 authors, including 11 of the ancient period, 32 scholars of the East of the middle ages. 49 works are related to exact Sciences, 25-natural Sciences, 24Humanities. It should be noted that this information is another result of our research on the topic. Based on this, the further increase in the number of works that were translated at the Toledo school and the expansion of the list of their authors in the course of our subsequent research is natural [14. p. 5-20].

\section{CONCLUSIONS}

The Foundation of the Toledo school was created during the Raimondo period. In particular, on his initiative and patronage, numerous translators from different parts of the region gathered here and launched the center's activities. And through the efforts of John and Rodrigo, various forms of assistance were provided, as a result, the activities of the center expanded much and rose to a new stage. This is what ensured the transformation of this place into a scientific school of its time. In the era of Alphonse X, although the scope of the school's activities narrowed, its former glory in a certain sense decreased, but at the same time, a number of reforms were implemented in the field of translation, which, in turn, played an important role in the formation of translation theory in Europe.

The Toledo school, which first appeared as a place of storage and collection of various rare works in Arabic, then turned into a place of their translation 


\section{EPRA International Journal of Research and Development (IJRD)}

and launch into circulation, in a short time became a scientific center for exchanging the experience of scientists of different nationalities, conducting discussions, writing research on the Sciences of that time.

As a result of the effective work of a whole group of translators who were engaged in creative work at the school, more than 120 books in Arabic belonging to different peoples, nationalities, faith and culture, concerning astronomy, mathematics, philosophy, medicine, geography, chemistry, biology, history, literature were translated into Latin. At the same time, the above-mentioned works became the intellectual property of the entire Western world and occupied an important place in the development of various branches of science in the region.

\section{REFERENCES}

1. Alverny, $M-T$ d'. (1982). "Translations and translators". Renaissance and Renewal in the Twelfth Century. p.p: 421-462.

2. Burnett, Ch. (2001). "The Coherence of the Arabic-Latin Translation Program in Toledo in the Twelfth Century". Science in Context. (14). p.p: 249-288.

3. Carmody, F.J. (1956). "Arabic Astronomical and Astrological Sciences in Latin Translation: A Critical Bibliography". Berkeley. California University Press. p.p: 193.

4. Fidora, A. (2010). "La Escuela de Traductores". La Catedral Primada de Toledo, dieciocho siglos de Historia. p.p: 480-483.

5. Foz, C. (1999). "Bibliografía sobre la escuela de traductores de Toledo". Quaderns: revista de traduccion.(4). p.p: 85-91.

6. Gargagliati, M. (1999). "La historia de la escuela de traductores de Toledo”. Quaderns. 1999. (4). p.p:9-13.

7. Grant, E.A. (1974). "Source Book in Medieval Science". Cambridge. Harvard University Press. p.p: 587.

8. Gil, J. (1990). "The Translators of the Period of Don Raimundo: Their Personalities and Translations (1125-1187)". Rencontres de cultures dans la philosophie medievale. Traductions et traducteurs de Antiquite tardive au XIVe siecle. p.p: 109-119.

9. Haskins, C.H. (1957). "The Renaissance of the Twelfth Century". Cambridge. Harvard University Press. p.p: 437.

10. Hayyek, S. (1990). "Escuela de Traductores. Toledo despensa cultural de Occidente". Islam Español. p.p: 219-220.

11. Henelde Abecasis, R. (1998). "Escuela de Traductores de Toledo Pasado y presente". Raíces, Revista judía de cultura. (35). p.p: $28-41$.

12. Makhmudov, O.V. (2017). "The Toledo Schoolearly center of investigation of the works Central Asian scholars in the Europe". Saarbrucken (Germany): Lambert Academic Publishing. p.
193. ISBN: 978-3-330-33405-2.

13. Makhmudov, O.V. (2017). "Some reasons about employees of the translator Domingo Gundisalvo in Toledo School". Austrian Journal of Humanities and Social Sciences. (1-2). p.p: 3-7.

14. Makhmudov, O.V. (2017). "Translations carried out in the Spanish translation centers (On basis of the works of scientists of antiquity and Muslim East)". Asian Journal of Multidimensional Research (AJMR). (6-2). p.p: 5-20.

15. Makhmudov, O. (2017). "Latin translations of the works Abū Bakr ar-Rāzt̄ and their values in development of the modern sciences". History, Problems and Prospects of Development of Modern Civilization. (18). p.p: 534-538.

16. Makhmudov, O.V. (2017). "Toledo School in the period of King Alfonso X". Proceedings of the $1^{\text {st }}$ International Conference on History, Sociology and Philosophy. (1). p.p: 3-7.

17. Махмудов, О.В. (2017). “Феномен Толедской школы и три этапа переводов". Евразийский Союз Ученых. (12-1 (45)). 5-9 [Makhmudov, O.V. (2017). "The phenomenon of the Toledo school and the three stages of translation". Eurasian Union of Scientists. (12-1 (45)). p.p: 5-9 (in Russ)].

18. Махмудов, О.В. (2017). 'Феномен Толедской школы и четыре этапа переводов". Всеобщая история. (3). 14-21 [Makhmudov, O.V. (2017). "The phenomenon of the Toledo school and the four stages of translation". General History. (3). p.p: 14-21. (in Russ)].

19. Robinson, M. (2007). "The Heritage of Medieval errors in the Latin Manuscripts of Johannes Hispalensis (John of Seville)". Al-Qantara. (28 (1)). p.p: 41-71.

20. Thorndike, L.A. (1964). "History of magic and experimental Science". New York. Columbia University Press. p.p: 835.

$$
\text { 2020 EPRA IJRD | Journal DOI: https://doi.org/10.36713/epra2016 |www.eprajournals.com |108 | }
$$

